УДК 349.3

Гаврилюк В.O.,

кандидат юридичних наук,

прокурор Закарпатської області

\title{
ПЕРЕВАГИ ТА НЕДОЛІКИ СОЦІАЛЬНОГО ЗАХИСТУ ПРАЦІВНИКІВ ПУБЛІЧнОї СЛУЖБИ
}

У статті йдеться про соиіальний захист праиівників державної служби. Мета статті полягає у з'ясуванні переваг та недоліків сучасного правового регулювання соціального захисту працівників публічної служби. Було виявлено, що соиіальний захист працівників публічної служби різниться залежно від категорії таких працівників та напряму діяльності органу публічної служби. У роботі висвітлено необхідність поліпшення соціального захисту прачівників державної служби шляхом створення загальних та єдиних норм закону щодо принципів та критерїв забезпечення такого захисту. Визначені у роботі переваги та недоліки сучасного правового регулювання соціального захисту працівників публічної служби можуть слугувати основою для побудови начіональної стратегї щэодо вдосконалення законодавства та роботи виконавчих органів України з даного питання.

Ключові слова: соціальне законодавство, соџіальний захист, публічна служба, працівник публічної служби, державна служба.

The article deals with the social protection of public service workers. The aim is to find out advantages and disadvantages of modern legal regulation of social protection of public service workers. Revealed that the social protection of public service workers varies depending on the category of such employees and the direction of public service activities. The paper highlighted the need for improved social protection for public service employees by creating common and uniform rules of law on the principles and criteria for providing such protection. Discussed in the article advantages and disadvantages of the current state of social protection of public service workers can be used as the basis of strategy to improve the work of legislative and executive power in Ukraine.

Keywords: social legislation, social protection, public service, public service worker, civil service.

Вступ. Одним із ключових завдань держави $є$ надання соціального захисту усім своїм громадянам, однак для працівників публічної служби такий захист дещо відрізнятиметься, оскільки вони перебувають не лише в адміністративних, але й трудових відносинах із державою, як роботодавцем. Як наслідок саме від державного забезпечення залежить можливість реалізації їх права на працю, належний матеріальний рівень та гідні умови життя, що відповідають економічним умовам. На сьогодні, правове регулювання публічної служби значно змінюється, що пов'язано із направленням ії діяльності згідно з новими концепціями публічного адміністрування та децентралізації, а також й усуненням застарілих виключно імперативних методів управління.

Варто наголосити, що питання соціального захисту відноситься до таких, що не можуть ігноруватись державою, а обсяг здійснення соціального захисту обмежуватись, оскільки саме від його рівня залежить можливість працівників публічної служби стабільно виконувати свої повноваження щодо надання послуг населенню та, власне, бути убезпеченим від настання непередбачуваних соціальних ризиків або мати можливість мінімізувати негативні наслідки від невідворотних соціальних ризиків. Саме тому, необхідним є дослідження переваг та недоліків соціального захисту працівників публічної служби за сучасним національним законодавством, що дозволить краще визначити напрями вдосконалення та відзначити позитивні тенденції розвитку, яких і потрібно дотримуватись надалі.

Завданнями даного дослідження є: 1) проаналізувати сучасні нормативно-правові акти щодо соціального захисту працівників публічної служби; 2) визначити переваги соціального захисту працівників публічної служби; 3) визначити недоліки соціального захисту працівників публічної служби.

Стан дослідження. Питання соціального захисту працівників публічної служби не втрачає своєї важливості уже тривалий час та його дослідженням займалась велика кількість науковців, однак у зв'язку із частим внесенням змін до національного законодавства такі наукові 
напрацювання не $\epsilon$ актуальними. Серед вчених, що проводили дослідження соціального захисту різних категорій працівників публічної служби можливо виділити наступних: О. Т. Барабаш, Ю. В. Баскакова, В. В. Безусий, Л. М. Булкат, С. О. Ветлинський, Д. М. Добровольський, В. С. Єгорова, В. О. Журавель, Г. С. Іванов, В. О. Маркова, І. В. Мигидин, О. Л. Назаренко, А. Л. Папікян, І. В. Пивовар, Т. В. Пустовойт, А. В. Пшонка, А. П. Рачинський, О. Ф. Толпиго, О. О. Шандула.

Основний зміст. На сьогодні, перелік працівників публічної служби встановлено ч. 17 ст. 4 Кодексу адміністративного судочинства України, відповідно до якої «публічна служба - діяльність на державних політичних посадах, у державних колегіальних органах, професійна діяльність суддів, прокурорів, військова служба, альтернативна (невійськова) служба, інша державна служба, патронатна служба в державних органах, служба в органах влади Автономної Республіки Крим, органах місцевого самоврядування» [1]. Таким чином, до працівників публічної служби зараховуються особи, що перебувають у трудових відносинах із державою в особі державних органів, так й з територіальною громадою. Їх спільною ознакою $є$ наявність владних повноважень, що й не дозволяє включити до переліку працівників державних та комунальних організацій, установ, а також й проведення діяльності щодо виконання державних завдань та надання послуг усьому суспільству, що відрізняє їх від приватних компаній. Саме тому, вони й потребують спеціального соціального захисту, який би враховував усі особливості та головне соціальні ризики, що можуть настати для працівника публічної служби. Однак, аналіз комплексу нормативно-правових актів, що регулюють дане питання свідчить про наявність як переваг, так й недоліків сучасного соціального захисту даної категорії працівників, що пов'язано із застосуванням неактуальних підходів до управління та правового регулювання. До переваг соціального захисту працівників публічної служби можливо віднести:

1. Спеціалізованість

2. Відповідність сучасній економічній ситуації

3. Забезпеченість

Щодо спеціалізованості, то найбільш яскраво це проявляється у соціальному захисті правоохоронних органів, кожен із яких має різний напрям діяльності. Так, соціальний захист суддів здійснюється через надання більшого часу на відпустку, адже ст. 136 Закону України «Про судоустрій і статус суддів» визначено, що «суддям надається щорічна оплачувана відпустка тривалістю 30 робочих днів з виплатою, крім суддівської винагороди, допомоги на оздоровлення в розмірі посадового окладу» [2]. Відмінність полягає у додатковій виплаті саме на оздоровлення, що для звичайних працівників лише в окремих випадках може супроводжувати відпустку, а отже й здійснюється захист, як фізичного, так й психологічного здоров'я судді, що безпосередньо буде впливати на його можливість якісно виконувати свої функції в майбутньому. Крім того, збільшеною $є$ й тривалість відпустки у порівнянні із тією, що встановлена КЗпПУ, а для судів із стажем більше 10 років, вона продовжується ще на 15 днів, що є доцільним для пропорційного збільшення часу відновлення до часу роботи та, власне, перебування у стресових ситуаціях.

Серед відмінних рис соціального захисту саме працівників прокуратури варто відзначити ч. 3 ст. 84 Закону України «Про прокуратуру», відповідно до якої «за пенсіонерами і членами їхніх сімей зберігаються гарантії соціального захисту, передбачені цим Законом та іншими законодавчими актами. Пенсіонери і члени їхніх сімей, що проживають разом із ними, мають також право на безкоштовне медичне обслуговування в тих медичних закладах, в яких вони перебували на обліку до виходу на пенсію прокурора» [3]. Тобто, гарантується стабільність рівня матеріальної допомоги та соціального забезпечення для прокурора та членів його сім'ї, щоб соціальний ризик настання пенсійного віку не мав негативних наслідків. Разом $з$ тим, положення щодо медичної безоплатної допомоги лише за тим місцем, де перебував прокурор на обліку під час служби є спірним, адже не враховує можливості переїзду. Дійсно, можливість отримувати безкоштовну медичну допомогу лише в одному місці є обгрунтованою, адже не дозволяє зловживати таким правом, однак таке соціальне забезпечення повинно взаємодіяти із правом на свободу місця проживання.

Щодо соціального захисту поліцейських, то він $є$ майже аналогічним до захисту державних службовців та працівників прокуратури, однак суттєва відмінність визначена ст. 103 Закону України «Про Національну поліцію України», відповідно до якої «особа, у якої один із батьків $\epsilon$ поліцейським та має вислугу в календарному обчисленні 20 років і більше, користується переважним правом зарахування до ліцеїв системи Міністерства внутрішніх справ України, до вищих навчальних закладів із специфічними умовами навчання, які здійснюють підготовку 
поліцейських, за умови успішного складання іспитів та відповідності іншим вимогам і правилам прийому до цих навчальних закладів протягом трьох років після здобуття необхідного для вступу рівня загальної середньої освіти» [4]. Тобто, соціальний захист самого працівника Національної поліції здійснюється через зменшення витрат на освіту членів його сім'ї. Важливим $\epsilon$ відповідність особи, що бажає вступити до спеціальних вищих закладів освіти усім стандартним вимогам щодо проходження зовнішнього незалежного оцінювання або конкурсу, що буде гарантією реальності бажання та можливості завершити таке навчання. Тож, спеціалізованість полягає у тому, що держава враховує специфіку тієї чи іншої діяльності публічного службовця, можливість настання соціального ризику, небезпечність його роботи для фізичного та психологічного здоров'я та на основі даних показників й визначає та поступово збільшує рівень соціального захисту.

Ще однією перевагою соціального захисту працівників публічної служби можливо вважати його відповідність економічній ситуації. Так, до прикладу ч. 4 ст. 20 Закону України «Про Уповноваженого Верховної Ради України з прав людини» передбачено, що «після закінчення строку повноважень, на який особу було обрано на посаду Уповноваженого, їй надається робота (посада), на якій вона працювала до призначення і яка зберігається за нею на час виконання нею обов'язків Уповноваженого, а в разі неможливості надання цієї роботи (посади) - інша рівноцінна робота (посада) на тому ж або, за ії згодою, іншому підприємстві, в установі, організації» [5]. Тобто, враховується потреба у забезпеченні належного матеріального становища особи та здійснюється іiі захист від соціального ризику щодо безробіття. Важливою умовою саме забезпечення відповідності економічній ситуації є право на переведення на рівнозначну посаду, що означає стабільність та гарантованість реалізації права на працю.

Також, прикладом соціального захисту, що враховує економічну ситуацію у державі та, власне, вартість придбання житла $\epsilon$ ст. 140 Закону України «Про судоустрій і статус суддів», де визначено, що «судді, члени їхніх сімей та їхнє майно перебувають під особливим захистом держави. Служба судової охорони, органи правопорядку зобов'язані вживати необхідних заходів для забезпечення безпеки судді, членів його сім'ї, збереження їхнього майна, якщо від судді надійде відповідна заява» [2]. Важливо, що захист прав на безпеку життя та здоров'я, а також на приватну власність поширюється не лише на суддю, але й на членів його родини, оскільки зрозумілою є їх соціальна роль та можливості вплинути на рішення судді саме через членів сім'ї. Варто наголосити, що існує окремий законодавчий акт, що регулює здійснення саме державного захисту усіх соціальний та природних прав правоохоронних органів, а отже й охоплює кожну небезпечну ситуацію, яка може виникнути та заходи щодо іï розв'язання. Тож, відповідність економічній ситуації полягає у тому, що, зазвичай, соціальний захист стосується або ж надання матеріальної допомоги у певному розмірі або покриття витрат на реалізацію соціального права, як то освіту, житло або медичну допомогу. Усі вони залежать саме від фінансових можливостей держави та економічних умов. Відповідність же забезпечується або ж визначення мінімального розміру, який зазвичай становить розмір заробітної плати або ж через покриття усіх витрат державою напряму, без доступу до таких коштів посередників.

Також, перевагою, можливо вважати забезпеченість, гарантування соціального захисту працівників публічної служби. Так, до прикладу у ст. 138 Закону України «Про судоустрій і статус суддів» визначено, що «після призначення на посаду суддя, який потребує поліпшення житлових умов, забезпечується службовим житлом за місцем знаходження суду органами місцевого самоврядування» [2]. Окрім того, що суддя забезпечується житлом, воно й знаходиться за місцем його працевлаштування, що дозоляє суттєво зекономити на тривалості дороги до суду та власне збільшити час відпочинку. Щодо обов'язку забезпечити реалізацію такої потреби, то закріплення його саме за органами місцевого самоврядування $є$ спірним, адже територіальна громада не обирає суддю самостійно, а отже й не повинна відповідати за його забезпечення.

Прикладом забезпеченості соціального захисту уже державних службовців стосується права на догляд за членами сім'ї. Так, ч. 3 ст. 41 Закону України «Про державну службу» визначено, що «не допускається переведення в іншу місцевість державного службовця - вагітної жінки або особи, яка є єдиним опікуном дитини віком до 14 років, а також державного службовця, який у встановленому законодавством порядку визнаний особою з інвалідністю; а п. 10 ст. 46 даного Закону, до стажу державної служби зараховуються: час перебування державного службовця у відпустці по догляду за дитиною до досягнення нею трирічного віку, а в разі якщо дитина потребує домашнього догляду до досягнення дитиною шестирічного віку» [6]. Позитивним 
у даному випадку є встановлення права не лише державно службовця-жінки, а працівника будьякої статті, який здійснює догляд за дитиною або ж є опікуном на соціальний захист, що виступає й гарантією рівності та недискримінації. Крім того, дана норма надає вищий рівень соціального захисту працівникам державної служби, ніж те передбачене Кодексом законів про працю.

Таким чином, забезпеченість, як перевага соціального захисту працівників публічної служби полягає у тому, що хоча й держава може змінювати самий обсяг соціального захисту, щодо права користуватись житлом для суддів або ж отримувати медичну допомогу закордоном для працівників поліції, однак мінімальний можливий рівень їх реалізації, що особливо стосується пенсійного забезпечення $є$ гарантованим та не може бути змінений законодавцем, оскільки суперечитиме Конституції України.

Разом $з$ тим, законодавство, що регулює діяльність працівників публічної служби не $\epsilon$ досконалим, а отже й серед недоліків сучасного соціального захисту таких працівників варто виділити такі:

1. Низька якість юридичної техніки

2. Соціальна неактуальність

3. Відсутність єдиних засад

Щодо низької якості юридичної техніки, то варто звернути увагу на правове регулювання соціального захисту військовослужбовців, що здійснюється Законом України «Про соціальний i правовий захист військовослужбовців та членів їх сімей», аналіз якого свідчить про наявність дублювання конституційних гарантій, як то право на свободу світогляду і віросповідання та недоторканності особи [7]. Найперше, виникає питання щодо необхідності такого повторення, адже наведеними конституційними правами володіє кожна людина. Крім того, такі права не доповнюються щодо способів та методів захисту саме щодо військовослужбовців, що теж свідчить про відсутність необхідності у їх дублюванні.

Також, відповідно до ч. 6 ст. 12 даного Закону «військовослужбовці, які мають вислугу на військовій службі не менше 17 років та потребують поліпшення житлових умов, мають право на одержання земельної ділянки для будівництва та обслуговування жилого будинку, господарських будівель і споруд в населених пунктах, обраних ними для проживання 3 урахуванням встановленого порядку. Органи місцевого самоврядування зобов'язані надавати земельні ділянки та в межах визначених законом повноважень допомогу в будівництві» [7]. Аналізуючи таку норму виникає питання щодо форми допомоги від органів місцевого самоврядування для такого будівництва та, власне іiі строкам. До прикладу, існує окремий порядок кредитування для отримання житла військовослужбовцями, що дозволяє чітко розуміти увесь процес отримання права власності на будинок чи квартиру. Однак, у даному випадку чітке коло повноважень органів місцевого самоврядування не визначено. Крім того, із даної норми можливо зрозуміти, що право на отримання земельної ділянки не має одноразового характеру, що дозволяє військовослужбовцю звертатись із відповідними заявами та отримувати земельні ділянки для будівництва житла на різних територіях, що уже має характер зловживання правом.

Таким чином, низька якість юридичної техніки, що проявляється у використанні застарілих юридичних формувань, як то «вищий навчальний заклад» для права на освіту осіб, один із батьків якого $є$ працівником поліції, а також й відсутність чітких обов'язків вповноважених органів щодо надання соціального захисту працівникам публічної служби, що породжує потребу у створенні окремих підзаконних актів.

Наступним недоліком соціального захисту працівників публічної служби є соціальна неактуальність. Так, звертаючись Так, звертаючись до соціального захисту державних службовців, то ст. 54 Закону України «Про державну службу» встановлено, що «державному службовцю у випадках і порядку, визначених Кабінетом Міністрів України, може надаватися службове житло. Державним службовцям може надаватися матеріальна допомога для вирішення соціальнопобутових питань» [6]. Тобто, соціальний захист стосується права на матеріальне забезпечення та житло, що у сукупності можливо вважати гарантіями втілення права на гідний рівень життя. Разом 3 тим, звертаючись уже щодо практики втілення права на житло, стає зрозумілим, що актуального порядку його втілення не визначено, а у державному бюджеті такого виду видатків не передбачено.

Щодо матеріальної допомоги, то вона встановлюється ст. 2 Порядку надання державним службовцям матеріальної допомоги для вирішення соціально-побутових питань, де визначено, що «державним службовцям матеріальна допомога може надаватися один раз на рік у розмірі 
середньомісячної заробітної плати на підставі особистої заяви» [8]. Таким чином, надання матеріальної допомоги є правом, а не обов'язком безпосереднього керівника державного службовця, що уже свідчить про не гарантованість їі отримання. Крім того, спірним $є$ визначення розміру такої допомоги саме як середньомісячної заробітної плати, оскільки необхідним $\epsilon$ врахування саме потреб працівника державної служби, а отже й більш доцільним $є$ встановлення переліку соціальних потреб, як то лікування, косметичний ремонт квартири або ремонт автомобільного транспорту, де визначити дещо збільшену суму матеріальної допомоги за наявності підтвердження іiі необхідності. У той же час, для матеріальної допомоги уже в інших випадках можливо встановити іiі розмір відповідний заробітній платі. Тож, такий недолік, як соціальна неактуальність полягає у невідповідності рівня соціального захисту вимогам та потребам суспільства та працівникам публічної служби, як його учасникам. Така неактуальність може й проявлятись через недостатність соціального захисту, як у випадку із службовцями органів місцевого самоврядування, так й у його надмірності, як то щодо додаткової відпустки для суддів, хоча праця прокурорів або ж працівників поліції $\epsilon$ не менш важкою, стресовою та соціально важливою.

Наступним недоліком соціального захисту працівників публічної служби є відсутність єдиних засад його здійснення. Так, Звертаючись, уже до аналізу Закону України «Про службу в органах місцевого самоврядування», можливо помітити, що окремих норм права щодо їх соціального захисту, тривалості відпусток або ж робочого дня не встановлено. Однак, ст. 2 Прикінцевих положень даного Закону визначено, що «дія Закону України «Про державну службу» поширюється на органи i посадових осіб місцевого самоврядування в частині, що не суперечить Закону України «Про місцеве самоврядування в Україні», цьому Закону та іншим законам України, що регулюють діяльність місцевого самоврядування» [9]. Таким чином, можливо дійти висновку, що соціальний захист працівників органів місцевого самоврядування $\epsilon$ аналогічним до соціального захисту працівників державної служби. Звісно, позитивним $\epsilon$ вирішення прогалини щодо недостатнього правового регулювання їх діяльності через застосування іншого законодавства. Водночас, служба саме в органах місцевого самоврядування має певні особливості щодо мети й призначення, а також повинна розвиватись в контексті децентралізації влади та відповідного й фінансування, а оскільки соціальний захист здійснюється саме державою, то це лише ускладнюватиме перехід до нового децентралізованого управління.

В той же час, соціальний захист народних депутатів здійснюється окремо щодо кожного права. Так, відповідно до ст. 35 Закону України «Про статус народного депутата України», «у витратах на забезпечення діяльності Верховної Ради України передбачаються кошти на оренду житла або винайм готельного номера. Право на отримання таких коштів мають народні депутати, не забезпечені житлом у місті Києві, і місце їх проживання, відповідно до його реєстрації, знаходиться на відстані понад 30 км від меж міста Київ» [10]. Тобто, найперше, значною є різниця між правовим регулюванням отримання права на житло суддею, державним службовцем та народним депутатом, порядок фінансування яких $є$ різним. У даному випадку, наявність коштів у бюджеті є гарантованою, коли ж право на отримання житла державним службовцем немає чіткої реалізації. Також, виникає питання щодо необхідності виділення сам коштів на оренду житла чи знімання готельного номеру, адже більш доречним була б побудова окремого житлового квартирного будинку, де б могли залишатись депутати під час сесійної роботи. Таким чином, можливо було б уникнути ситуації із зловживання правом та необгрунтованим збільшенням витрат на оренду, а наявність власного житлового приміщення дозволяла б використовувати його депутатами різних скликань.

Тож, створення окремого нормативно-правового акту щодо соціального захисту працівників публічної служби дозволило б закріпити принципи та критерії його здійснення базові обов'язки держави та органів місцевого самоврядування, а також й мінімально можливі рівні. Зі свого боку, це дозволило б уникнути сучасної негативної ситуації щодо неоднорідності соціального захисту при фактичному однаковому навантаженні на працівників публічної служби та їх можливості зловживання правами та застосовувати корупцію для збільшення власного рівня соціального захисту.

Висновки. Отже, на основі проведеного аналізу можливо зрозуміти, що необгрунтованість вибору рівня матеріального забезпечення та загальність правового регулювання соціального захисту, не дозволяють створювати окремі соціальні гарантії для тих працівників публічної служби, для яких ймовірність настання соціального ризику є вищою. Застарілість же нормативно- 
правового регулювання, що створює мертве законодавство, яке, хоча і $€$ чинним, але фактично не може бути втіленим для здійснення соціального захисту таких працівників. Звісно, позитивним $\epsilon$ стабільність та гарантованість отримання мінімального розміру соціального забезпечення та, власне, захисту, однак критерії визначення мінімальних потреб далеко не завжди є об'єктивним. Тож, виділення переваг та недоліків соціального захисту працівників публічної служби свідчить, що його правове регулювання потребує значного вдосконалення в контексті синхронізації із європейськими тенденціями державного та місцевого управління. Крім того, необхідним $\epsilon$ створення нормативно-правового акту, що регулював би основи соціального захисту для усіх видів працівників публічної служби, що дозволило б гарантувати рівність даного захисту.

\section{СПИСОК ВИКОРИСТАНИХ ДЖЕРЕЛ:}

1. Кодекс адміністративного судочинства України: Закон України 06.07.2005 № 2747IV.Відомості Верховної Ради України (ВВР). 2005. №35. С. 1358

2. Про судоустрій і статус суддів: Закон України від 02.06.2016 № 1402-VIII. Відомості Верховної Ради України (ВВР).2016. № 31. С. 7.

3. Про прокуратуру: Закон України від 14.10.2014 № 1697-VII. Відомості Верховної Ради України(ВВР). 2102. №2. С. 54.

4. Про Національну поліцію: Закон України від 02.07.2015 № 580-VIII.Відомості Верховної Ради України(ВВР). 2015. №40. С. 1970.

5. Про Уповноваженого Верховної Ради України з прав людини: Закон України від 23.12.1997 № 776/97-ВР. Відомості Верховної Ради України. 1998. № 20. С. 99.

6. Про державну службу: Закон України від 10.12.2015 № 889-VIII. Відомості Верховної Ради України (ВВР). 2016. №.4 С. 43.

7. Про соціальний і правовий захист військовослужбовців та членів їх сімей: Закон України від 20.12.1991 № 2011-ХІІ. Відомості Верховної Ради України (ВВР). 1991. № 15. С. 190.

8. Про затвердження Порядку надання державним службовцям матеріальної допомоги для вирішення соціально-побутових питань: Постанова Кабінету Міністрів України від 08.08.2016 № 500. Офіційний вісник України. 2016. № 65. С. 44.

9. Про службу в органах місцевого самоврядування: Закон України від 07.06.2001 № 2493-III. Відомості Верховної Ради України (ВВР).2001 № 33. С. 175.

10. Про статус народного депутата України: Закон України від 17.11.1992 № 2790-XII. Відомості Верховної Ради України (ВВР). 1993 № 3. С. 17.

УДК 349.2

Малюга Л.Ю.,

кандидат юридичних наук, стариий науковий співробітник юридичного факультету, доцент кафедри трудового права та права сочіального забезпечення Київського начіонального університету імені Тараса Шевченка

\section{ПРАКТИЧНІ ПРОБЛЕМИ СОЩАЛЬНОГО ЗАКОНОДАВСТВА В УМОВАХ ЄВРОІНТЕГРАЦЇ̈ УКРАЇНИ ТА ШЛЯХИ ЇХ ВИРІШЕННЯ}

У статті проаналізовано недоліки, прогалини та проблеми соиіального законодавства в умовах євроінтеграиії України. Досліджено зміст і значення кожної з них. Розроблено чіткі шляхи вирімення вказаних проблем. Розкрито напрями удосконалення соиіального законодавства в умовах євроінтеграчї України.

Ключові слова: сочіальне законодавство, свроінтеграчія Украӥни, сочіальні стандарти, проблеми правового регулювання, соціальні гарантії.

In the article the shortcomings, gaps and problems of social legislation in the context of Ukraine's European integration are analyzed. The content and significance of each of them are investigated. There are clear ways to solve these problems. The directions of improvement of social legislation in the conditions of European integration of Ukraine are revealed. 